\title{
Extremely Thermophilic Gram-negative Bacteria from Hot Tap Water
}

\author{
By ROSEMARY PASK-HUGHES AND R. A. D. WILLIAMS \\ Department of Biochemistry, The London Hospital Medical College, \\ London EI $2 A D$
}

(Received I8 November I974; revised 28 January I975)

\begin{abstract}
SUMMARY
Two strains of heterotrophic, non-motile, Gram-negative extreme thermophiles have been isolated from hot tap water. These strains (NH and DI) have been characterized and compared with strains of the genus Thermus. Few of the single organic compounds tested supported growth in the presence of ammonium salts, and, like Thermus strains, growth on undefined media was restricted to dilute tryptone-yeast extract-mineral salt solutions. Nutrient agar and similar common laboratory media did not support growth. The growth rate was similar to that of Thermus strains, as was the unusual pattern of antibiotic resistance. Mean base composition of $\mathrm{NH}$ was $6 \mathrm{I} \cdot 4 \%$ guanine plus cytosine $(\mathrm{G}+\mathrm{C})$, and of DI was $62 \cdot 0$ to $62 \cdot 2 \% \mathrm{G}+\mathrm{C}$, which are several per cent lower than the $\mathrm{G}+\mathrm{C}$ contents of other strains so far described.
\end{abstract}

\section{INTRODUCTION}

The interest in bacteria which grow at high temperatures was given new impetus by the description of Thermus aquaticus (Brock \& Freeze, 1969), an aerobic, yellow-pigmented, Gram-negative, heterotrophic bacterium with an optimum growth temperature of $70^{\circ} \mathrm{C}$. The original isolates were from hot springs in Yellowstone National Park, Montana, and in California, U.S.A., but it was observed that similar isolates could be obtained from hot tap water and a spring receiving thermal pollution, but not from cold tap water or cold springs. Ramaley \& Hixon (1970) isolated a strain which lacked yellow pigment, but which otherwise resembled Thermus aquaticus, from a stream receiving hot water effluent in Bloomington, Indiana, U.S.A. They proposed that the pigment protected the cells in hot springs against sunlight, and that non-pigmented strains, if they grew faster than pigmented ones, would have a selective advantage in the dark environment of hot water tanks. Many similar strains, mostly non-pigmented, were subsequently purified from the water tanks of laundries and homes in Madison, Wisconsin, U.S.A. (Brock \& Boylen, 1973). A yellowpigmented strain, originally called Flavobacterium thermophilum (Oshima \& Imahori, 197I) and isolated from the Mine Hot Spring, Shizuoka, Japan, has been compared with Thermus aquaticus and renamed Thermus thermophilus (Oshima \& Imahori, 1974). A pink-pigmented isolate from Yellowstone National Park which was morphologically distinct from Thermus, and had an alkaline optimum $\mathrm{pH}$ for growth, has recently been allotted to another new genus, Thermomicrobium (Jackson, Ramaley \& Meinschein, 1973).

This paper forms part of a study of thermophilic bacteria as a source of thermostable enzymes, and describes two cultures enriched from the hot tap-water of two separate hot water systems at The London Hospital. 


\section{METHODS}

Strains used. Hot tap water (100 $\mathrm{ml}$ ) was mixed with $100 \mathrm{ml}$ medium containing final concentrations of $0 . \mathrm{I} \%(\mathrm{w} / \mathrm{v})$ tryptone (Difco) and $0 . \mathrm{I} \%(\mathrm{w} / \mathrm{v})$ yeast extract (Difco), with $10 \%(\mathrm{v} / \mathrm{v})$ of mineral salts (Ramaley \& Hixon, 1970). This mixture was incubated 3 days at $70{ }^{\circ} \mathrm{C}$ as a shallow layer in a bottle lying on its side. The turbid cultures were streaked on the above medium plus agar $2 \%(\mathrm{w} / \mathrm{v})$. The Petri dishes were incubated overnight sealed in polythene bags to prevent drying out. Individual colonies were restreaked repeatedly, and the purified cultures freeze-dried in brain-heart infusion broth plus serum.

Strain $\mathrm{YT}_{1}$, the type strain of Thermus aquaticus (Brock \& Freeze, 1969) was supplied by the A.T.C.C. (strain No. 25I04). Strain $\mathrm{X}_{1}$ (Ramaley \& Hixon, 1970) was kindly donated by Dr R. Ramaley.

Growth on single substrates. Agar plates $(2 \%, \mathrm{w} / \mathrm{v})$ were prepared containing $0.2 \%(\mathrm{w} / \mathrm{v})$ substrate, together with $0.05 \%(\mathrm{w} / \mathrm{v})\left(\mathrm{NH}_{4}\right)_{2} \mathrm{SO}_{4}$ and $10 \%(\mathrm{v} / \mathrm{v})$ mineral salts solution (Ramaley \& Hixon, 1970). Each strain was streaked on a whole plate for each substrate. Plates were incubated at $70{ }^{\circ} \mathrm{C}$ and examined on the 3 rd and 5 th days for growth. If every time that growth was tested it was sparse and limited to the primary inoculum streak, this was attributed to carry-over of nutrients from the inoculum and scored as negative growth.

Determination of growth rate. A thermal gradient incubator (Scientific Industries International Inc. (U.K.) Ltd., Loughborough) was used with tubes containing $20 \mathrm{ml}$ of growth medium (GM), comprising final concentrations of $0.3 \%(w / v)$ yeast extract, $0.3 \%(w / v)$ tryptone, together with $10 \%(\mathrm{v} / \mathrm{v})$ mineral salts solution. The tubes were shaken at 45 oscillations per minute so that a bubble traversed the length of the culture tube at each oscillation. Growth was measured turbidimetrically with an EEL 222 colorimeter.

Antibiotic resistance. Plates containing GM plus $2 \%(w / v)$ agar were flooded with a culture of each strain and air-dried until no free fluid was evident on the agar surface. Oxoid 'Multodiscs' were then applied to the plates, which were incubated in polythene bags at $70{ }^{\circ} \mathrm{C}$. The zone size, from the edge of a disc to the edge of bacterial growth, was measured after 5 days.

Bulk growth of bacteria. Portions $(500 \mathrm{ml})$ of $\mathrm{GM}$ were used in 21 Erlenmeyer flasks fitted with baffles to increase aeration. Cultures were incubated at $70{ }^{\circ} \mathrm{C}$ in a Gallenkamp IH620 rotary shaking incubator at $\mathrm{I} 50 \mathrm{rev} . / \mathrm{min}$. Bacteria were harvested by centrifugation $(5700 \mathrm{~g})$ for $15 \mathrm{~min}$, washed three times with distilled water and stored at $-20^{\circ} \mathrm{C}$.

Spectrophotometry of pigments. Approximately $6 \mathrm{~g}$ wet wt bacteria were dispersed in $10 \mathrm{ml}$ boiling methanol and the pigments allowed to extract for $30 \mathrm{~min}$. The spectrum of the clear supernatant after centrifugation was recorded between 310 and $510 \mathrm{~nm}$ using a PerkinElmer 402 spectrophotometer.

Preparation of extracts. Ice-cold bacterial suspensions were disrupted with a sonic disintegrator, or by pressing in a Biox Press (Nacka, Sweden). Unbroken bacteria and debris were removed by centrifugation at $170000 \mathrm{~g}$ for $2.5 \mathrm{~h}$, and the supernatant was used immediately or stored at $-20^{\circ} \mathrm{C}$.

Spectrophotometry of cytochrome. A difference spectrum of the extract versus the same reduced with freshly prepared sodium dithionite solution was scanned between 390 and $590 \mathrm{~nm}$ by using a Perkin-Elmer 402 spectrophotometer.

Preparation and analysis of DNA. Washed whole bacteria were treated with trypsin $(0.2 \mathrm{mg} / \mathrm{ml}$ in $0.2 \mathrm{M}$-phosphate buffer $\mathrm{pH} 8.0)$ at $37^{\circ} \mathrm{C}$ for $3 \mathrm{~h}$ and then recovered by centrifugation $(5700 \mathrm{~g}$, I $5 \mathrm{~min}$.). Lysis was carried out with $2 \%(\mathrm{w} / \mathrm{v})$ sodium laurylsulphate at 
$70{ }^{\circ} \mathrm{C}$ for $15 \mathrm{~min}$. DNA was isolated by the method of Marmur (1961). Where DNA was not precipitated in a form that could 'be spooled' up on a glass rod, the preparation was left at $4{ }^{\circ} \mathrm{C}$ and the nucleic acid removed by centrifugation (I $400 \mathrm{~g}$, IO $\mathrm{min}$ ). Pure DNA solution was dialysed for 3 days at $4{ }^{\circ} \mathrm{C}$ against 500 vols. of the appropriate buffer, and the hyperchromicity due to thermal denaturation and the melting temperature determined with a Gilford model 240 spectrophotometer. The cell was heated by circulating ethylene glycol, and the temperature measured with a thermistor probe in a metal pocket inserted through the cap of the cell. The temperature was read with a thermistor thermometer (Grant Instruments Developments, Ltd, Barrington, Cambs.) which was checked against a mercury thermometer with a certificate of calibration (British Standards Institute). Both standard saline-citrate (Marmur \& Doty, I962) and $0^{\circ} \mathrm{I} \times$ standard saline-citrate (Shildkraut $\&$ Lifson, 1965) were used. DNA prepared from T. aquaticus $\mathrm{YT}_{1}$ was used as a standard.

Assay and heat inactivation of enzymes. Malate dehydrogenase was assayed by measuring the increase in extinction at $340 \mathrm{~nm}$ due to the reduction of NAD by malate. The assay mixture comprised $25 \mu \mathrm{l}$ of suitably diluted bacteria-free extract in a $3 \mathrm{ml}$ cuvette, and contained $30 \mu$ mol-malate, I $\mu$ mol-NAD, $45 \mu$ mol-EDTA and $450 \mu$ mol-tris at $\mathrm{pH} 9.5$. Iso citrate dehydrogenase was assayed similarly with $25 \mu \mathrm{l}$ of diluted extract in a $3 \mathrm{ml}$ cuvette, the extract containing I $\mu$ mol-isocitrate, Io $\mu$ mol- $\mathrm{MgCl}_{2}, 0.5 \mu \mathrm{mol}-\mathrm{NADP}$ and I $2 \mu \mathrm{mol}-$ sodium diethylbarbiturate at $\mathrm{pH} 8 \cdot 5$. Assays were performed at $45{ }^{\circ} \mathrm{C}$. Heat inactivation was studied by sealing $0.3 \mathrm{ml}$ of extract diluted in the appropriate buffer in a glass ampoule and totally immersing these in an oil bath at 90,95 or $100{ }^{\circ} \mathrm{C}$. Multiple ampoules were used and one was withdrawn at each time interval, cooled in ice-water, and maintained at $4{ }^{\circ} \mathrm{C}$ until assayed for enzyme activity. Buffer solutions used for inactivation experiments were $50 \mathrm{mM}$-phosphate $\mathrm{pH}_{7} \cdot 6$ for malate dehydrogenase, and 40 mM-diethylbarbiturate $\mathrm{pH} 8.5$ for isocitrate dehydrogenase.

\section{RESULTS}

\section{Isolation of strains}

After 3 days' incubation all enrichment media became turbid. Of ten cultures of hot tap water, from this Institution and private houses, all contained Gram-positive bacteria but two also had substantial growth of Gram-negative bacteria. One Gram-negative strain was purified from each of these two cultures by restreaking well-isolated colonies on yeast extract-tryptone plates. After two days at $70^{\circ} \mathrm{C}$ the colonies were buff-coloured, compact, smooth and with entire margins. The two strains, designated NH and DI, originated in separate hot water systems.

Both strains were aerobic, non-motile, non-sporulating rods which sometimes formed filaments. Growth occurred on the dilute GM in liquid culture and on plates, but not on commonly used bacteriological media such as nutrient agar, blood agar, Rogosa agar and MacConkey agar.

\section{Growth on single substrates}

Like the Thermus strains already described (Brock \& Freeze, I969; Ramaley \& Hixon, 1970), strains DI and NH grew on few single organic compounds (Table I) with ammonium sulphate as a nitrogen source. When distinct growth occurred the colonies were smaller than they would have been on yeast extract-tryptone, although the colonial appearance was similar. Strains $\mathrm{NH}, \mathrm{YT}_{1}$ and $\mathrm{X}_{1}$ grew significantly on both glycerol and glutamate. Strain DI grew sparsely and inconsistently on glycerol, but not on glutamate or any other substrate tested. 
Table I. Growth on agar plates containing single substrates

\begin{tabular}{|c|c|c|c|c|}
\hline \multirow{2}{*}{$\begin{array}{l}\text { Substrate } \\
(0.2 \%, w / v)\end{array}$} & \multicolumn{4}{|c|}{ Strain } \\
\hline & $\mathrm{YT}_{1}$ & $x_{1}$ & NH & DI \\
\hline Glucose & - & - & - & - \\
\hline Fructose & - & - & - & - \\
\hline Arabinose & - & - & - & - \\
\hline Xylose & - & - & - & - \\
\hline Sucrose & \pm & - & + & - \\
\hline Starch & - & - & - & - \\
\hline Succinate & \pm & \pm & - & - \\
\hline Citrate & \pm & - & - & - \\
\hline Acetate & + & + & - & - \\
\hline Malate & - & - & - & - \\
\hline Formate & - & \pm & - & - \\
\hline Mannitol & - & + & - & - \\
\hline Glycerol & + & + & + & \pm \\
\hline Alanine & - & - & - & - \\
\hline Glycine & - & - & - & - \\
\hline Glutamate & + & + & + & - \\
\hline
\end{tabular}

+ , Distinct growth; \pm , growth slight and irregular and sometimes limited to the primary inoculum streak; -, no growth.

\section{Growth rate on liquid media}

The growth curve for $T$. aquaticus $\mathrm{YT}_{1}$, determined in a thermal gradient incubator (Fig. I), resembles in shape that published by Brock \& Freeze (I969) for shake flask cultures, but in our experiments the optimum growth temperature was 69 rather than $70{ }^{\circ} \mathrm{C}$. The shape of the growth curve for isolate DI was similar to that for $\mathrm{YT}_{1}$, with the optimum at $69^{\circ} \mathrm{C}$. Strain $\mathrm{NH}$ grew rapidly in a broader range of temperature, the optimum being at $70^{\circ} \mathrm{C}$. At $55^{\circ} \mathrm{C}$ the mean doubling time for $\mathrm{NH}$ was I I4 min, almost exactly twice the value at the optimum temperature. By contrast the corresponding difference in mean doubling time was threefold for DI.

\section{Antibiotic sensitivity}

The patterns of resistance to antibiotics in four strains of Gram-negative thermophiles (Table 2) were similar. Notable is the general sensitivity of all strains to penicillin, except that $\mathrm{YT}_{1}$ was less sensitive than the other strains to ampicillin. Strains NH and DI differed from those previously described in their resistance to sulphafurazole.

\section{Pigments and cytochrome}

The packed bacteria and colonies of NH and DI appear to have little pigmentation. Illumination of growing bacteria on agar or in liquid medium did not stimulate pigmentation. Methanol extracts of $\mathrm{YT}_{1}$ and $\mathrm{DI}$ gave a distinct peak at $400 \mathrm{~nm}$ which was absent in similar extracts from strain NH. Neither NH nor DI showed any trace of the prominent pigment peaks at 450 and $475 \mathrm{~nm}$ observed in T. aquaticus $\mathrm{YT}_{1}$. Aqueous extracts of both new strains, when reduced with sodium dithionite, showed prominent peaks in the regions 420 , 520 to 525 , and 555 to $560 \mathrm{~nm}$, characteristic of $c$-type cytochromes. Fig. 2 shows the difference spectrum of $\mathrm{NH}$, in which $\alpha$ and $\beta$ peaks for cytochrome $c$ itself (5I 8 and $550 \mathrm{~nm}$ ) are evident. Pronounced peaks at 524 and $557 \mathrm{~nm}$ may have been due to cytochrome $c_{1}$ but the shoulder at $530 \mathrm{~nm}$ and the peak at $557 \mathrm{~nm}$ may have been due to cytochrome $b$. It is also possible that type $a$ cytochromes contributed to the peak at $550 \mathrm{~nm}$, but no shoulder at 430 to $450 \mathrm{~nm}$ was observed in the difference spectrum. 


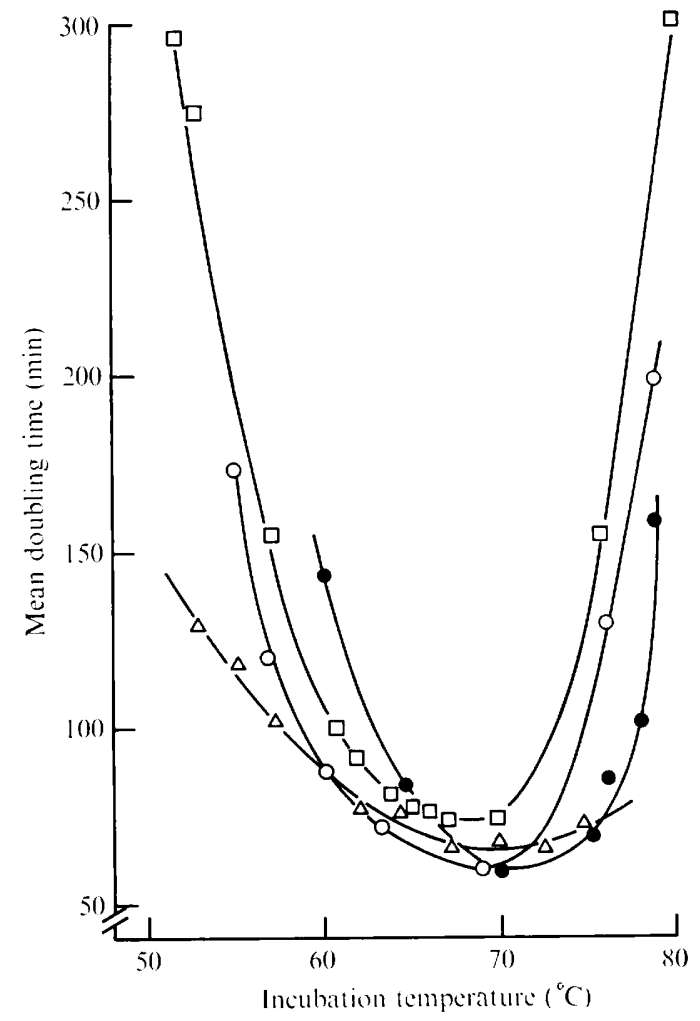

Fig. I

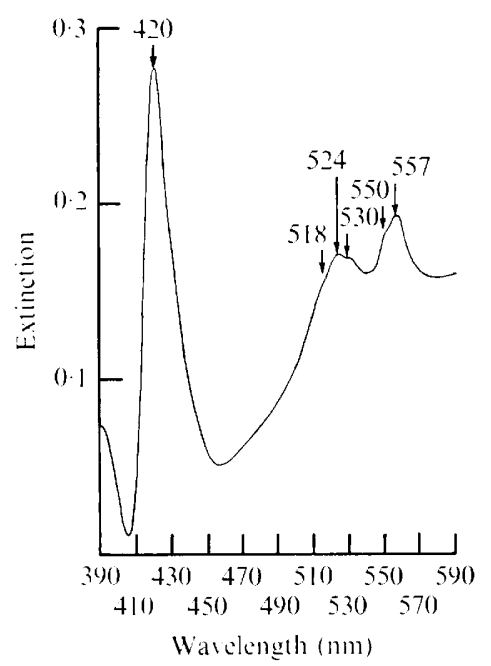

Fig. 2

Fig. I. Growth temperature profile of T. aquaticus $\mathrm{YT}_{1}$. D, Data of Brock \& Freeze (I969) for shake flask cultures of $\mathrm{YT}_{1} ; O$, determinations with the thermal gradient incubator with $\mathrm{YT}_{1}$; $\square$, strain DI; $\triangle$, strain NH.

Fig. 2. Difference spectrum of oxidized versus reduced cytochromes in extract of strain NH.

Table 2. Resistance to antibiotics in Oxoid Multodiscs

Antibiotic

Fusidate

Colistin

Kanamycin

Neomycin

Novobiocin

Cloxacillin

Ampicillin

Methicillin

Penicillin

Chloramphenicol

Erythromycin

Sulphafurazole

Streptomycin

Tetracycline

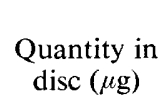

10
50
5
10
5
5
2
10
5 (units)
50
50
500
25
50

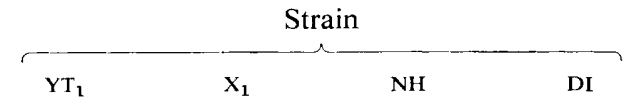

$+++t+$

++
+
+
+
+
-
-
-
-
-

$\begin{array}{cc}+++ & ++ \\ ++ & + \\ + & + \\ - & - \\ ++ & ++ \\ - & - \\ - & - \\ - & - \\ - & - \\ - & - \\ - & - \\ ++ & ++ \\ - & - \\ ++ & ++\end{array}$

+++ , No zone of inhibition; ++ , zone less than $6 \mathrm{~mm}$ from edge of disc; + , zone greater than $6 \mathrm{~mm}$ from edge of disc; - , zone of inhibition too large to read; \pm , result sometimes + , sometimes - . 
Table 3. Mean base composition of DNA of Gram-negative thermophiles

\begin{tabular}{|c|c|c|c|}
\hline \multirow[b]{3}{*}{ Strain } & \multicolumn{3}{|c|}{$\% \mathrm{G}+\mathrm{C}$, determined by } \\
\hline & \multirow{2}{*}{$\begin{array}{l}\text { Density-gradient } \\
\text { centrifugation }\end{array}$} & \multicolumn{2}{|c|}{ Thermal denaturation in: } \\
\hline & & $\mathrm{SSC}$ & $0 \cdot \mathrm{I} \times \mathrm{SSC}$ \\
\hline \multicolumn{4}{|l|}{ Thermus aquaticus } \\
\hline $\mathrm{YT}_{1}$ & $67 \cdot 4 \dagger$ & $65 \cdot 4$ & $64 \cdot 4$ \\
\hline $\mathrm{YT}_{1}-\mathrm{VII}-56 \mathrm{I} 4 \mathrm{C}$ & $65 \cdot 4 \dagger$ & - & 一 \\
\hline YT-VII-5ID & $65 \cdot 4 \dagger$ & - & 一 \\
\hline YT-VII-563A & $65 \cdot 4 \dagger$ & - & - \\
\hline Thermus sp. $\mathrm{x}_{1}$ & $64-65 t$ & - & - \\
\hline Thermomicrobium roseum & $64 \cdot 3 \ddagger$ & - & - \\
\hline Thermus thermophilus $\mathrm{HB} 8$ & $68 \cdot 4^{*}$ & $68 \cdot 8^{*}$ & $66 \cdot 9^{*}$ \\
\hline Strain NH & - & $6 \mathrm{I} \cdot 4$ & NT \\
\hline Strain DI & - & $62 \cdot 2$ & $62 \cdot 0$ \\
\hline
\end{tabular}

SSC, standard saline-citrate; NT, not tested.

* Oshima (I 972).

$\dagger$ Brock \& Freeze (1969).

$\ddagger$ Jackson et al. (1973).

Table 4. Heat inactivation of enzymes

Time taken to reduce enzyme activity by half ( $\mathrm{min}$ )

\begin{tabular}{|c|c|c|c|c|c|c|}
\hline \multirow[b]{2}{*}{ Strain } & \multicolumn{3}{|c|}{ Malate dehydrogenase } & \multicolumn{3}{|c|}{ Isocitrate dehydrogenase } \\
\hline & $90^{\circ} \mathrm{C}$ & $95^{\circ} \mathrm{C}$ & $100{ }^{\circ} \mathrm{C}$ & $90^{\circ} \mathrm{C}$ & $95^{\circ} \mathrm{C}$ & $100{ }^{\circ} \mathrm{C}$ \\
\hline$Y_{1}$ & 230 & 40 & $5 \cdot 5$ & $17 \cdot 5$ & $5 \cdot 8$ & 3.0 \\
\hline $\mathrm{NH}$ & I94 & 30 & $4 \cdot 5$ & I I $\cdot 5$ & $2 \cdot 4$ & I 6 \\
\hline DI & I 80 & 30 & $4 \cdot 5$ & $190^{\circ}$ & $3 \cdot 1$ & $I \cdot 3$ \\
\hline
\end{tabular}

\section{DNA base composition}

Strains NH and DI have DNA mean base compositions of $6 \mathrm{I} \cdot 4$ and $62 \cdot 2 \%$ by thermal denaturation in standard saline-citrate (Table 3), which places these strains at the lower end of the range of $\%$ guanine plus cytosine $(\mathrm{G}+\mathrm{C})$ amongst Gram-negative extreme thermophiles. In the same solvent the mean base composition of $\mathrm{YT}_{1} \mathrm{DNA}$ was estimated to be $2 \% \mathrm{G}+\mathrm{C}$ lower than the value reported by Brock \& Freeze (I969).

\section{Heat inactivation of enzymes}

The stability of both malate dehydrogenase and isocitrate dehydrogenase is greater in strain $\mathrm{YT}_{1}$ than in $\mathrm{NH}$ or $\mathrm{DI}$, and malate dehydrogenase is the more stable enzyme in all strains and at all temperatures (Table 4). The time course of decay of active enzyme in the sealed tubes was always sigmoid, but less so at $90{ }^{\circ} \mathrm{C}$ than at $100{ }^{\circ} \mathrm{C}$. The increase in activity of isocitrate dehydrogenase, particularly from $\mathrm{YT}_{1}$, over the first part of the heat treatment was due to reversal of cold inactivation of enzyme stored in the refrigerator. The times of half inactivation were all calculated from the activities at time zero. 
DISCUSSION

The two isolates described seem similar to the non-pigmented Gram-negative extreme thermophiles found growing in laundry heaters by Brock \& Boylen (I973), and are probably strains of the genus Thermus. Isolates NH and DI grew well on dilute tryptone-yeast extract broth with mineral salts under aerobic conditions, but failed to grow on the more concentrated media, such as nutrient agar, that support the growth of spore-forming thermophiles. Streaking on such plates has therefore been used routinely to check for contamination with bacilli. No spores or Gram-positive bacteria have been observed in cultures over a period of two years.

Strain $\mathrm{YT}_{1}$ was found to grow, sometimes sparsely, on sucrose, succinate, citrate, acetate and glutamate in agar plates. These results agree with those of Brock \& Freeze (I969), but moderate growth was also observed on glycerol which supported the growth of all four strains. Isolate DI grew less well than the other strains upon glycerol, but it failed to grow on any other substrate. The exacting nutritional requirements of NH and DI, which are presumably reflected in their restricted ability to grow on single substrates, offers little hope for the use of these strains in physiological and genetic studies which require defined media.

The shape of the curve of growth rate versus temperature for $\mathrm{NH}$ resembled that of $T$. thermophilus HB8 (Oshima \& Imahori, 1974) rather than that of T. aquaticus $\mathrm{YT}_{1}$ (Brock \& Freeze, 1969). It may be that in water tanks the fluctuation in temperature as water is used and reheated may tend to select thermophilic strains capable of growth in a broad temperature band. The temperature of tap water from the systems in question lies in the range 55 to $68{ }^{\circ} \mathrm{C}$, hence there may be little selective pressure on the upper temperature limit for growth in these strains.

The unusual pattern of antibiotic resistance amongst the Gram-negative extreme thermophiles has been noted for T. aquaticus $\mathrm{YT}_{1}$ (Brock \& Freeze, 1969), Thermus sp. $\mathrm{x}_{1}$, Thermomicrobium roseum (Jackson et al. 1973) and T. thermophilus (Oshima \& Imahori, 1974). The present strains broadly conform to this pattern. All the Gram-negative extreme thermophiles are very sensitive to the penicillins, as well as to neomycin, streptomycin, chloramphenicol and erythromycin.

Spectrophotometry of a methanol extract of cells of NH and DI did not reveal any indications of the presence of the carotenoid pigments which are such an obvious feature of several other Gram-negative extreme thermophiles (Brock \& Freeze, 1969; Heinen et al. 1971; Oshima, 1972; Jackson et al. 1973). The isolates of Brock \& Boylen (I973) either were not pigmented or were very pale yellow, and these authors suggested that carotenoid pigments might confer an advantage on bacteria growing in sites exposed to sunlight. There would be no selective pressure to retain such pigments in bacteria growing for prolonged periods in dark situations. The suggestion that loss of pigment might confer a selective advantage over hypothetical pigmented ancestral strains, in that the growth rate might be thus improved, cannot be tested. However, Brock \& Boylen (1973) have not reported growth rates for their strains, and our isolates grew slightly less rapidly than $T$. aquaticus $\mathrm{YT}_{1}$ and much less rapidly than another pigmented strain, T. thermophilus HB8. It therefore seems unlikely that loss of pigment is associated with such a selective advantage.

Difference spectra of the soluble fraction showed marked peaks for $c$-type cytochromes together with $c_{1}$ or $b$ cytochromes. No unequivocal evidence of $a$ cytochrome is presented, however. McFeters \& Ulrich (1972), using difference spectra and low temperature spectra, detected cytochromes $a, a_{3}, b$ and $c$ in $T$. aquaticus $\mathrm{YT}_{1}$ preparations, and it seems likely that the electron transport chains in the Gram-negative thermophiles may prove to be similar. 
The mean base composition of DNA from T. aquaticus $\mathrm{YT}_{1}$ was estimated to be $67.4 \%$ $\mathrm{G}+\mathrm{C}$ by caesium chloride density gradient centrifugation. However, our own estimate by thermal denaturation in standard saline citrate was $65.4 \% \mathrm{G}+\mathrm{C}$. Such differences are commonly found between results obtained in different laboratories by different methods. However, when results obtained in our own laboratory are compared, the two new strains have 3.2 and $4.0 \%$ less $\mathrm{G}+\mathrm{C}$ than does $\mathrm{YT}_{1}$. Thus the present strains have the lowest $\% \mathrm{G}+\mathrm{C}$ of all the Thermus-like isolates so far tested and it would be of great interest to compare mean composition of their DNA with that of other non-pigmented strains.

The present isolates, while interesting strains of bacteria, show no advantages over $T$. aquaticus $\mathrm{YT}_{1}$ as sources of thermostable malate dehydrogenase or isocitrate dehydrogenase. The growth rates, optimum temperatures for growth, and growth yields on tryptone-yeast extract are similar, and the enzymes in extracts of $\mathrm{YT}_{1}$ are somewhat more resistant to thermal inactivation than those of the new strains. The inability of $\mathrm{NH}$ and DI to grow on substrates likely to increase the specific activity of these enzymes in the bacteria also means that improvement of enzyme yield is unlikely to be attained by the use of these strains. The sole advantage which they seem to possess is freedom from pigment; the carotenoids of $T$. aquaticus, together with a slime which it produces, do cause some problems in protein purification.

Work on the thermal stability and properties of malate dehydrogenase was supported by the Science Research Council. Funds for purchase of the thermal gradient incubator were provided by the Royal Society.

\section{REFERENCES}

Brock, T. D. \& Boylen, K. L. (I973). Presence of thermophilic bacteria in laundry and domestic hot-water heaters. Applied Microbiology 25, 72-76.

Brock, T. D. \& Freeze, H. (I969). Thermus aquaticus gen.n. and sp.n., a non-sporulating extreme thermophile. Journal of Bacteriology 98, 289-297.

Jackson, T. J., Ramaley, R. F. \& Meinschein, W. G. (1973). Thermomicrobium, a new genus of extremely thermophilic bacteria. International Journal of Systematic Bacteriology 23, 28-36.

Heinen, U. J., Klein, G., Klein, H. P. \& Heinen, W. (I97I). Comparative studies on the nature and distribution of pigments from two thermophilic bacteria. Archiv für Mikrobiologie 76, I8-27.

MARmur, J. (I96I). A procedure for the isolation of deoxyribonucleic acid from micro-organisms. Journal of Molecular Biology 3, 208-2 I 8.

Marmur, J. \& Doty, P. (I962). Determination of the base composition of deoxyribonucleic acid from its thermal denaturation temperature. Journal of Molecular Biology 5, I09-I I8.

McFeters, G. A. \& Ulrich, J. T. (1972). Effect of temperature on the respiration and cytochromes of an extreme thermophile. Journal of Bacteriology 110, 777-779.

Oshima, T. (I972). Studies on an extreme thermophile, Flavobacterium thermophilum Hв8. In Molecular Evolution: Prebiological and Biological, pp. 399-423. Edited by D. L. Rohlfing and A. L. Oparin. New York: Plenum Press.

Oshima, T. \& ImAhoRi, K. (197I). Isolation of an extreme thermophile and thermostability of its transfer ribonucleic acid and ribosomes. Journal of General and Applied Microbiology 17, 5I 3-517.

Oshima, T. \& ImahoRI, K. (I974). Description of Thermus thermophilus (Yoshida and Oshima) Comb. Nov. A non-sporulating thermophilic bacterium from a Japanese thermal spa. International Journal of Systematic Bacteriology 24, 102-I I 2.

Ramaley, R. F. \& Hixon, J. (1970). Isolation of a non-pigmented, thermophilic bacterium similar to Thermus aquaticus. Journal of Bacteriology 103, 527-528.

SChildkraut, C. \& LifSon, S. (I965). Dependence of the melting temperatures of DNA on salt concentration. Biopolymers 3, 195-208. 